Journal of MMIJ Vol.131 p.614- 618 (2015)

(C)2015 The Mining and Materials Processing Institute of Japan

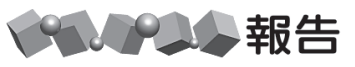

Technical Report
海底硫化物マウンドを対象とした 採掘システムの検討と沖縄実海域での採掘試験結果 *

\author{
川 野 誠 矢 ${ }^{1}$ \\ 増 田 信 行 $^{3}$ \\ 岡 本 信 行 $^{1}$
}

\title{
Study on Mining System for Seafloor Massive Sulfide Mound and Results of On-Site Excavation Tests in Okinawa Trough
}

\author{
by Seiya KAWANO ${ }^{\mathrm{a}^{*}}$, Takahiro KAWAI ${ }^{\mathrm{a}}$, Nobuyuki MASUDA ${ }^{\mathrm{b}}$, \\ Jiro YAMATOMI ${ }^{\mathrm{c}}$ and Nobuyuki OKAMOTO ${ }^{\mathrm{a}}$
}

a. Japan Oil, Gas and Metals National Corporation, 10-1 Toranomon 2-chome, Minato-ku, Tokyo, 105-0001(*Corresponding author, E-mail: kawano-seiya@jogmec.go.jp)

b. International Center for Research and Education on Mineral and Energy Resources (ICREMER), Akita University, 1-1 Tegata Gakuen, Akita, 010-8502

c. Department of system innovation, school of engineering, The university of Tokyo, 7-3-1 Hongo, Bunkyo-ku, Tokyo 113-8656

\begin{abstract}
Japan Oil, Gas and Metals National Corporation (JOGMEC) has started an exploration program for Seafloor Massive Sulfides (SMS) in the EEZ of Japan, and launched investigations on mining and processing technologies for SMS and studies for environmental impacts caused by SMS developments. With regard to the mining technologies, the studied mining system for SMS consists of three units: which are mining tools working on seafloor, riser and lifting systems, and production support vessels with unloading facilities onto shuttle ships. Physico-mechanical characteristics of the seafloor sulfides, which are key parameters for designing mining systems, have not fully clarified yet to apply for design purposes. Because exploration campaigns and geological characterizations are still undergoing. However, two types of mining tools for testing on seafloor were developed as the mining unit. Excavation tests on the actual SMS site with the depth of $1,600 \mathrm{~m}$ in the Okinawa Trough, south-west of Japan, were conducted in 2012. Functions of the mining tools, such as cutting abilities for seafloor sulfides, moving and maneuvering performances, and climbing capabilities on slopes steeper than 25 degrees were examined in the tests. This paper describes the outline of the proposed mining system and mining tools for SMS, as well as the results of on-site subsea mining tests in the Okinawa Trough.
\end{abstract}

KEY WORDS: Seafloor Massive Sulfide, Mining Technologies, Lifting Technologies, Mining Tools for SMS, Subsea Mining Tests

$$
\text { 1. はじめに }
$$

独立行政法人石油天然ガス・金属鉱物資源機構 (JOGMEC) は, 経済産業省 (METI) からの委託を受け, 研究機関, 大学, 民間企 業の協力の下, 平成 21 年 3 月に策定された海洋エネルギー・鉱 物資源開発計画 ${ }^{3)}$ に基づいた海底熱水鉱床の開発に関わる取り 組みを実施してきた。

この計画では最終的に商業化のための経済性評価を実施するこ

*2014 年 4 月 26 日受付 2014 年 8 月 19 日受理

1. 正会員 (独) 石油天然ガス・金属釷物資源機構 金属資源技術部海洋資源 技術課

2. (独) 石油天然ガス・金属鉱物資源機構 資源探查部 探査第二課

3. 正会員 秋田大学 国際資源学教育研究センター

4. 正会員 東京大学大学院工学系研究科名誉教授

[著者連絡先] FAX: 03-6758-8058 (JOGMEC・川野) E-mail: kawano-seiya@jogmec.go.jp

キーワード：海底硫化物マウンド，採鉱技術，揚鉱技術，採掘試験機，実 海域実験
とを目的に資源量評価, 採鉱, 選鉱製錬, 環境影響評価の 4 つの 分野を同時並行に進めることとされた。採鉱分野では特に資源量 評価分野で順次得られる鉱床に関するデータを基に以下の通り採 鉱システムの検討を進めてきた。

第 1 期前半 3 年 (平成 $20 \sim 22$ 年度) は海底熱水鉱床の採鉱シ ステム全体の基本構成を決定し, システムを構成する 3 つのユ ニット (採掘ユニット・揚鉱ユニット・採鉱母船ユニット) の基 礎的検討を行った ${ }^{1,5-8)}$ (Fig. 1)。

前半の 3 年は, 採掘対象を固結した塊状硫化物とし, これがマ ウンド内に存在するものとして, クローラによりマウンドとその周 辺を走行でき, 掘削を担う採掘試験機による採鉱手順を検討した。

後半 2 年 (平成 23 年度〜平成 24 年度) は, 第 2 期の目標とし て掲げられていた海洋実証試験の規模等について机上検討すると ともに, 採掘ユニットに期待される要素技術 ( 掘削 ・ 集鉱・走行 要素技術等) の基礎データを収集するために, 採掘試験機を製作 


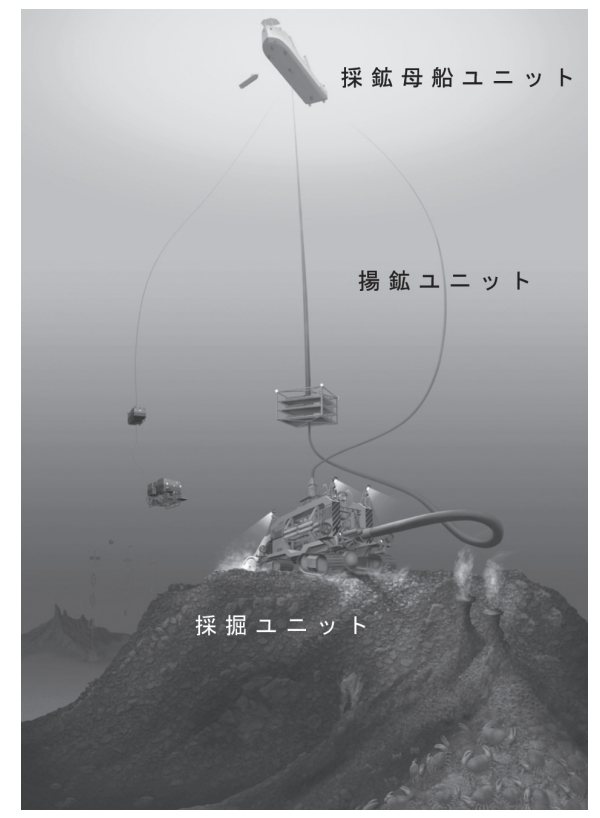

Fig.1 Illustration of SMS mining system.

し，陸上・水槽・実海域における試験を実施し，商業機開発に必 要と考えられるデータを取得し, 解析した。

また，採鉱対象とした海底熱水鉱床は硫化岩が集積してマウン ド状の地形を形成しており（以下，海底硫化物マウンド)，採鉱 対象の地山特性を把握することを目的とした地質調査や，海底着 座型ボーリング装置 (BMS) から得られた掘削ログデータ等を解 析し, 海底硫化物マウンド内部の地山特性の推定を試みた ${ }^{2)}$ 。

海洋鉱物資源の開発は我が国のみならず海外でも注目を浴びて おり，直近では Nautilus Minerals 社が水深 1,600m における海底 熱水鉱床を採掘するための掘削装置を完成させたというニュース リリースを発表した。この装置はナミビア共和国で IHC Marine and Mineral Projects 社が水深 $50 \mathrm{~m}$ の海底からのダイヤモンド浚渫 に使用している自走式の浚渫クローラーを発展させたものである が，掘削・浚渫装置は大水深域の海底鉱物資源開発の実績はな い。大水深域の試験としては, Korea Institute of Ocean Science and Technology (KIOST) がマンガン団塊採鉱のための集鉱装置を製作 し水深 $1,000 \mathrm{~m}$ 超の海域で試験を実施した実績はあるが，マンガ ン団塊が賦存する実海域 (水深 $5,000 \mathrm{~m} \sim 6,000 \mathrm{~m}$ ) での試験には 至っていない。

以下に採鉱分野における海底熱水鉱床の採掘システムの検討と 実海域 (水深 $1,600 \mathrm{~m}$ ) における海底硫化物マウンドを対象とした 採掘試験について現在までの検討状況を報告する。

\section{2. 採掘システムの検討}

\section{$2 \cdot 1$ 採鉱条件}

海底熱水鉱床の賦存が確認されている沖縄海域及び伊豆・小笠 原海域について, 日本海洋データセンターが保有する当該海域の 気象データを基に, 採鉱システムの稼働時及び待機時の気象条件 を設定した。

採鈗システムを検討するために, 既に資源量評価分野のボーリ ング等から得られているデータを基にして下記条件を想定した。

・採鉱対象は海底から盛り上がったマウンドとする

・マウンドの規模は, 直径約 $100 \mathrm{~m}$, 比高約 $20 \mathrm{~m}$ とする

・マウンド表面は, 直径数 $10 \mathrm{~cm} \sim 1 \mathrm{~m}$ 程の碩によって被覆さ れている (Fig. 2)

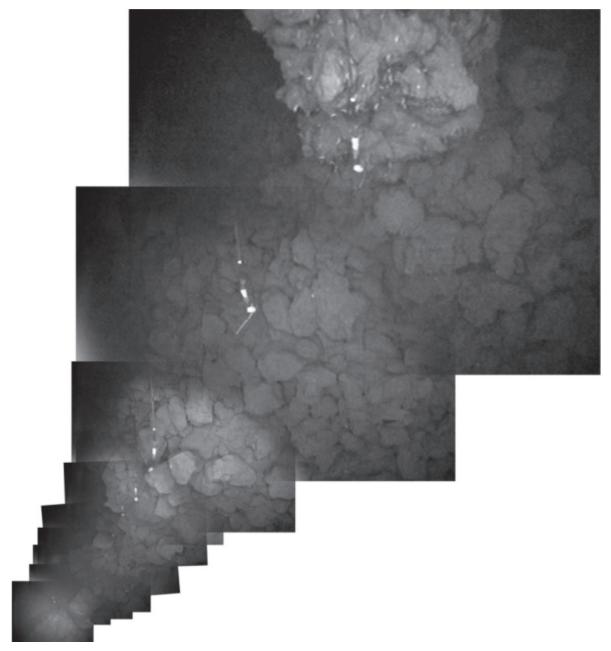

Fig.2 A part of the SMS mound covered by large boulders and gravels in the Okinawa Trough Region.

・マウンド山頂部にはチムニーが存在する

・マウンド内部は比較的均質で硬質な硫化岩により構成されて いる

・鉱石と見なした硫化岩の一軸圧縮強度は，採取したサンプル の力学試験より, 平均 $20 \mathrm{MPa}$ 程度 (最大 $50 \mathrm{MPa}$ ) とする

・採掘方式は, マウンド頂部から下方に向かって, 機械掘削に よるベンチカットで採掘することを基本とする

・採掘一集鉱一揚鉱システムの設計条件として, 掘削産物の最 大粒径を $5 \mathrm{~cm}$ 以下とする

・採鉱対象海域として伊豆・小笠原海域及び沖縄海域を想定し, 海象条件 (波高等) より，年間を通じて 95\%の稼働率とし， $99.8 \%$ の待機（避難せず現場滞在）が可能である

- 予察的な経済性評価により, 商業化の条件として, 一日当た りの粗鉱生産量は，湿潤重量で 5,000 トンが生産規模である と設定する

\section{$2 \cdot 2$ 採掘システムの構成}

採鉱システムを構成する 3 つのユニット (採掘・揚鉱・採鉱母 船）について上記の条件下での仕様等について基礎的な検討を実 施した。

採掘ユニットについては, 自走式の採鉱機あるいは集鉱機に, 集鉱した鉱石を移送するためのフレキシブルホースをつなぎ，揚 鉱ユニットに流送する方式を基本に検討を行っている。フレキシ ブルホースの最適な材料については, 硫化岩石片を含むスラリー の流送による管壁の耐磨耗・腐食性等を考慮し, 選定するべく検 討を進めている。

採鉱機 (集鉱機) については後述する 2 種類の小型の採掘試験 機を製造し, 陸上・水槽・実海域での試験を実施しながら, 実機 の仕様を検討している。

揚鉱方法としてバケット方式，ライザーを利用したエアリフト 方式とポンプ方式の計 3 種類を机上で比較検討し, バケット方式 はコスト面での優位性があるが生産性は低いこと, エアリフト方 式はメンテナンス性は良いが生産性のばらつきや操作性（制御） の難しさがあること，ポンプ方式は生産性や操作性で優位である がメンテナンス面で前者に劣ること等, 生産性, 操作性等の利点・ 欠点を総合的に考慮した結果, 石油開発等で実績のあるポンプ方 式を選定した。

ポンプについてはダイアフラム型水中ポンプおよびターボ型水 中ポンプの 2 種類で概念設計を行い, コストを試算した結果, シ 
ステム重量, 所要電力などの面でターボ型水中ポンプがコスト的 に優位であることを確認した。ライザーについてはフレキシブル ライザーとリジッドライザーの 2 種類について, 水槽での自由動 摇試験を行い, 強潮流下での挙動を観測し, 水槽実験で得られた パラメータを用い，実海域で予想される渦励振挙動について計算 機シミュレーションを行った。さらに, ライザーについても，概 念設計とコス卜分析等を行い, 結果を比較検討して, リジッドラ イザーが優位であることがわかった。

採鉱機, ライザー管の投入・揚収・運転の点から比較検討を 行った結果, 海象の影響が少ない船体中央から安定してライザー を吊り降ろせるムーンプール式，また，採鉱対象が一か所に集中 していないことによる採鉱場所の頻繁な移動の必要性を考慮し, 現時点では, 係留方式と比較し DPS (Dynamic Positioning System) 方式による定点保持を行う舟形の採鉱母船が有利であるとした。 母船からシャトル船への払い出しは 5 日に 1 回のペースで実施 するものと想定した結果，母船に備えるホールド (保管容量) は $24,000 \mathrm{~m}^{3}$ とした。シャトル船への払い出し (積み替え) は舷側係 留 - 機械式払出し方式とし, 実海域の海象条件下における稼働率 を検討した。スラリー鉱石からの脱水については，採鉱母船に機 械式の脱水設備を装備することとして, 固液分離後の排水を排水 管により深海まで戻すシステムを検討した。

\section{3. 採 掘 試 験}

\section{$3 \cdot 1$ 採掘要素技術試験機}

採鉱機及び集鉱機に係る各種の要素技術 ( 走行・集鉱・掘削技 術等) に関する技術的評価を行うことを目的として，2機の小型 の採掘試験機 (以下, 試験機) を製造し, 陸上・水槽試験の後, 沖縄海域水深 $1,600 \mathrm{~m}$ の実海域で試験を実施した。以下に各試験 機の概要を記述する。

(1) 試験機 $\mathrm{A}$ 試験機 $\mathrm{A}$ は，チムニー等の掘削を主な目的と し，マウンドを整地するための 2 軸カッターヘッドと, 整地され た面を下向きに効率的に掘削することを目的としたドラムカッ ターヘッドの 2 種類のカッターヘッドを備え, 船上にてヘッドの 交換が可能である。いずれの掘削ヘッドでも，中央には集鉱ノズ ルがついており，掘削しながら集鉱することができる点が後述の 試験機 B と異なる。掘削・集鉱された掘削片は，試験機後部に 取り付けられた採鉱ホールドに集められ，粒度分布測定等に供さ れる。

走行方式は 4 クローラによる自走式で, 各クローラはシリン ダー制御により，前後・左右の高さ・傾きの調整が可能となって いる。

（2）試験機 B 試験機 B は，掘削と集鉱を別々の機械によっ て行うものとして, 採鉱機の掘削ヘッドは, 炭鉱などの岩盤坑道 掘進等で実績を有するロードヘッダー型のものを用いている。試 験機の掘削ヘッドを集鉱へッドに交換することで集鉱機とするこ ともできる。

走行方式は 2 クローラ方式で, 機体の重心は低く, シンプルな 構造となっている。試験機後部にはアウトリガーを備え, 掘削反 力が取れないときは，これを地面に突き刺すことで反力を得るこ とができる。

\section{$3 \cdot 2$ 実海域での採掘試験}

平成 24 年 8 月から 11 月にかけて, JOGMEC が所有する海底 鉱物資源探査船『白嶺』に上述の試験機 $\mathrm{A}, \mathrm{B}$ を搭載し, 排他的 経済水域 $(\mathrm{EEZ})$ 内の水深 $700 \mathrm{~m} \sim 1,600 \mathrm{~m}$ に分布する海底熱水鉱 床の採掘を検討する目的で, 沖縄海域の既に資源量評価の対象と なっている海底硫化物マウンドを選定し, それぞれ 20 日程度の

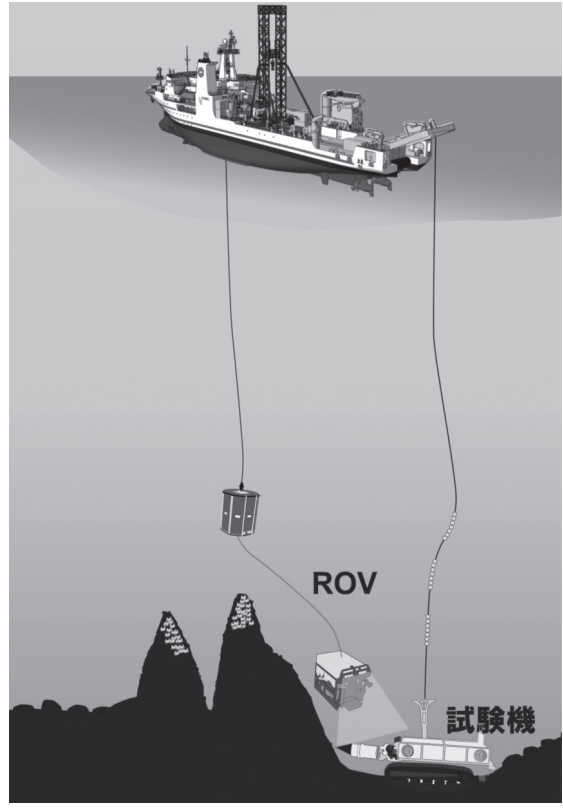

Fig.3 Illustration of mining tests carried out in 2012 in the Okinawa Trough Region.

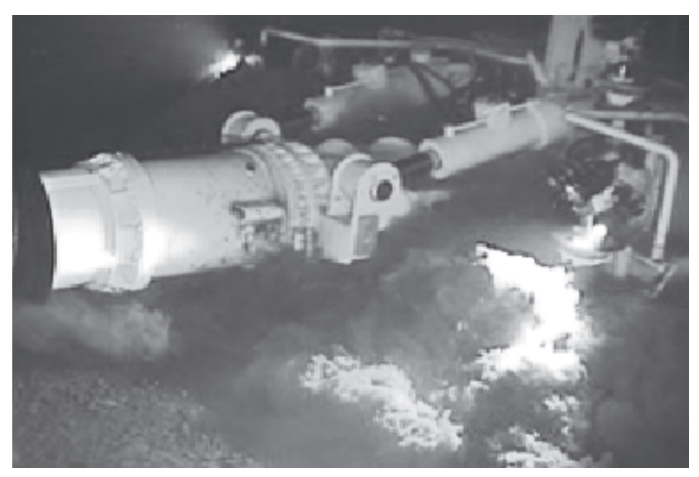

Fig.4 "Mining Tool B" working on 1,600m depth seafloor in Okinawa.

採掘試験を実施した。試験項目は下記のものである。

(1) 投入・揚収状況の確認試験

(2) 走行状況の確認試験

(3) 掘削状況の確認試験

（4）集鉱状況の確認試験（試験機 Aのみ）

(5) 掘削ヘッドの耐久試験 (ピック耐久，機械耐久 )

(6) 総合試験 $((1) \sim(4)$ に係る一連の試験 )

また，併せて採掘による環境への影響を把握するためのデータ を取得した。さらに, 海底での試験機の動作状況を同時に投入し た ROV ( 遠隔操作型無人探査機)により観察した (Fig. 3)。

Fig. 4 に実際に水深 $1,600 \mathrm{~m}$ の海底を走行する試験機 B を示す。 実海域試験では, 海底のソナー映像により, 走行・掘削状況をモ ニタリングした。走行試験では傾斜 $25^{\circ}$ 以上の斜面の登坂可能な ことを確認した。Fig. 5 は, 試験機の左後部に取り付けられた全 方位ソナーの映像で, 円の中心にあるソナー位置から 360 度方向 を投影している。映像の右側に縦に平行な 2 本の筋が見えるが, これが試験機 B の走行跡で, 鮮明に写し出されている。掘削試 験後に，ROV を用いて掘削箇所を確認した (Fig. 6)。

試験機 Aについては, 走行・掘削状況を確認するとともに, 掘削と同時に試験機後方に搭載した鉱石ホールドに掘削片を集鉱 した。集鉱した掘削片の重量及び粒度分布を測定し,カッターヘッ 


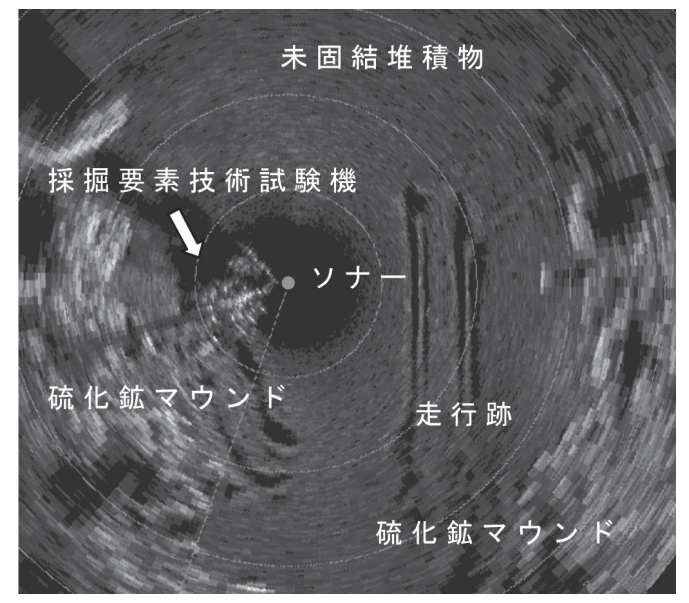

Fig.5 An image of seafloor sonar showing crawlers' trails of the "Mining Tool B" and surrounding mounds as well as the testing tool itself.

ド及びピックのサイズや形状の選定，集鉱効率に関するデータを 取得した。

両試験機とも，『白嶺』から問題なく投入・揚収できることを 確認した。また，総合試験により，投入〜走行〜掘削〜集鉱〜揚 収までの一連の作業を確認した。一方で耐久性については，試験 時間が十分でなかったために試験機のメンテナンス性 (ピックの 交換頻度等) を詳細に評価できるまでには至らなかった。

なお, 試験の実施に当たっては, 試験内容, 試験期間を考慮し, 事前に採掘試験による周辺環境への影響を検討し, 環境に重大な 影響が生じないことを慎重に確認した。また，事前の影響予測結 果を検証するため, 試験中及び事後にも濁度や水中雑音等に関す る環境モニタリング測定を行い, 掘削による環境影響を評価した。

\section{4. 採掘試験より得られた課題}

実海域での試験により，陸上試験では確認されなかった以下の 課題を抽出した。

(1) 海底硫化物マウンド周辺に賦存する泥質の軟弱堆積物の上 での試験機の走行は困難なこと。

(2) 掘削屑が巻き起こす水中の懸濁により視界が完全に遮られ ること。

(3) 海底硫化物マウンドの急峻な地形のため計測される位置情 報が不安定化し位置精度が確保できないこと。

（4）マウンド表面に分布する砂を掘削した場合，大粒径 $(5 \mathrm{~cm}$ 径 を大きく越える粒度) の掘削片の発生は不可避であること。

これらの課題に対し, 対応を検討した結果は以下の通りである。 軟弱堆積物上の走行については, クローラの接地圧を低減する ことで, 走行状況の改善が可能である。また, 採掘方式を見直す ことにより, 軟弱堆積物上の走行を避けた採掘の可能性が残って おり, 採掘方式の見直しとあわせて, 今後検討することにする。

掘削屑が巻き起こす縣濁については, スラスタで流れ場を形成 し縣濁粒子を吹き飛ばすことで視界を確保する手法や, 音響ソ ナ一等のセンサー系を増強することで, 視認性が強化され運用性 が向上すると考えられる。

位置情報の不安定化については, 慣性航法装置の搭載や, 海底 基準点 (トランスポンダー) を設置することで, 試験機の正確な 位置把握が可能となる。

海底硫化物マウンド表層を覆う礫は, カッターによる機械掘削 の障害物となりうること, また掘削片の粒度の均一化に課題があ るので, 今後, 大型バケット等による碩除去や, 揚鉱ユニットに

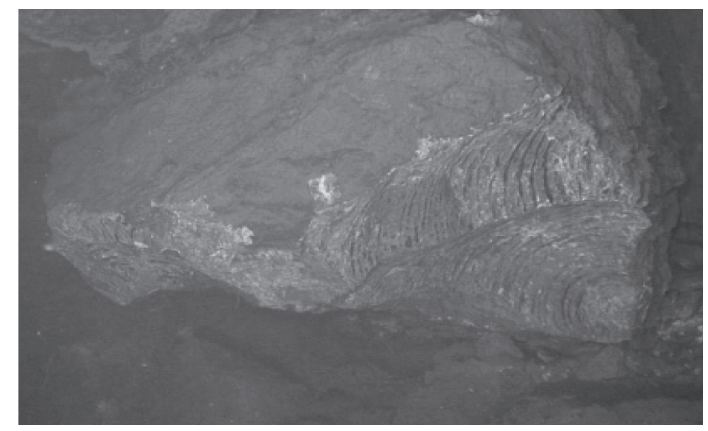

Fig.6 Cutting marks left on the sulfide rock by the "Mining Tool B".

移送する前に粒径を揃えるための破砕機の導入等を検討する必要 がある。

\section{5. まとめと考察}

以上で述べたとおり，今までの検討と実海域での採掘試験によ り解決すべき課題が抽出されるとともに, 水深 $1,600 \mathrm{~m}$ の海底に おいては硫化物マウンドを対象に機械掘削が技術的に可能なこと を明らかにした。当初，採鉱技術の検討にあたって，それまでの 地質学的知見を基に，採掘対象であるマウンド内部は比較的均質 で硬質な硫化岩の連続体であると想定していたが, 試験機の設計・ 製作が始まった以降のボーリング調査, 深海底カメラによる観察 やパワーグラブによるサンプリング，マウンド斜面の切削調査に より，マウンド表層部を被覆する硫化岩磕は予想以上に厚く，資 源量にも相当量が算定されていることから掘削対象として想定す る必要があるとの認識に至っている。

一方, ボーリング機械能力の限界などから, 現状ではマウンド 深部での鉱石の賦存状況や地山特性などをほとんど把握できてい ない。今後は『白嶺』に搭載された最新鋭の掘削装置等を用いた マウンド深部の調查等により, 鉱床全体の地山特性や硫化岩 / 鉱 石の賦存状況をより正確に把握していくことが優先度の高い課題 を考えている。また, 採掘試験機を用いた水深 $1,600 \mathrm{~m}$ の実海域 での掘削・集鉱・走行の要素試験で取得したデータや知見等を基 に, 深海底での採鉱機械のオペレーション技術や採掘手順も含め た採掘ユニットの仕様について更に検討を進めていく必要がある。

揚鉱ユニットについては定性的・定量的な比較評価により，リ ジッドライザーを用いたターボ型水中ポンプ方式が有力である。 更に，揚鉱管やポンプ等の機器類の材料は耐摩耗性・腐食性を考 慮して選定する必要がある。

採鉱母船ユニットについても，概念設計まで実施したが，更な る詳細仕様の検討については採掘ユニット, 揚鉱ユニットの仕様 を定めた後に，再度検討する必要があると考えている。

本稿では, 採鉱一集鉱一揚鉱システムの一連の検討が行われた ことを紹介したが, それは一つの可能性を提示しているに過ぎ ず，その他のシステムの可能性を否定するものではない。今後の 資源量評価や環境影響評価などの結果によって, 適宜, 見直す必 要があると考えている。また, 実際の商業化の際には, 事業実施 者の視点での更なる比較検討に基づいた機器の選定や仕様の検討 を行った上で採鉱システムを構築する必要があることは言うまで も無い。今後は, 進捗状況を見極めつつ全体を整合して計画を進 め, 方向性の確認 - 見直しや総合的な検証を行うなど, 計画的に 各段階で評価を行い, 開発を推進していく必要がある.

なお, 第 1 期の成果を踏まえ, 平成 25 年 12 月に海洋エネルギー・ 鉱物資源開発計画 ${ }^{4)}$ が改訂された。その中に, 採鉱分野に関し て第 1 期の成果と課題及び第 2 期の計画が, 次のように記されて 
いる。

（1） 1 期（平成 21 年度～平成 24 年度 ) の成果 海底熱水鉱 床開発計画の第 1 期では, 暫定的な経済性評価に基づき, 商業生 産規模を 1 日 5,000 トンとして, 海底熱水鉱床の採鉱システムを

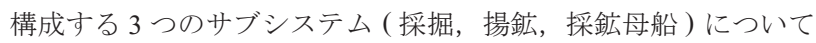
最適な方式を検討した。

このうち, 採掘については, 沖縄海域伊是名海穴内の海底熱水 鉱床において，2 種類の採掘試験機を投入し，世界初の掘削試験 に成功し，将来の商業機開発に資する有用なデータを取得した。

(2) 課題掘削屑が巻き起こす懸濁粒子による視界のきかな い海底での操業を可能にする可視化技術, 大水深対応水中ポンプ, ライザー管 ( 揚鉱管) の設計等の技術的課題を克服し，商業レ心゙ ルの採鉱・揚鉱技術を確立する。

(3) 2 期 (平成 25 年度〜平成 30 年度 ) の計画深部ボーリ ング等による解析結果から鉱床全体の地山モデル (構成する鉱 床・岩盤の力学及び物性モデル) を構築するとともに, 詳細資源 量に基づく経済性評価をべースとして採鉱基礎条件を設定する。
また，実海域での採鉱一揚鉱パイロット試験等を通じて，平成 29 年度までに採鉱・揚鉱分野の要素技術を確立する。

謝辞本調査は経済産業省の委託業務で実施された。経済産 業省並びに本業務に携わった関係各位に感謝の意を表します。

\section{References}

1)「海底熱水鉱床の開発計画」第 1 期中間評価, 経済産業省, (2011)

2）「海底熱水鉱床の開発計画」第 1 期最終報告書, 経済産業省, (2013)。

3) 海洋エネルギー・鉱物資源開発計画, 経済産業省, (2009)

4) 海洋エネルギー・鉱物資源開発計画, 経済産業省, (2013)

5) 金属資源レポート,【事業紹介】海底熱水鉱床の平成 21 年度の取り組み成果と新 調查船の建造，JOGMEC，(2010）。

6）金属資源レポート,【事業紹介】新海洋資源調查船の建造について一海洋資源の探 査, 開発を加速するため一, JOGMEC, (2011) .

7）金属資源レポート,【事業紹介】JOGMEC の海底熱水鉱床の開発に向けた取り組み の状況と国際状況，JOGMEC，(2011）

8）金属資源レポート【事業紹介】海洋鉱物資源の開発に向けた調査の取組状況, JOGMEC, (2011).

9) JOGMEC プレスリリース, 海底採掘要素試験機による海底熱水鉱床の採掘試験に 成功, 平成 24 年 9 月 25 日 (2012). 